Kujamäki, P. (2016). "And then the Germans came to town": The lived experiences of an interpreter in Finland during the Second World War. Linguistica Antverpiensia, New Series: Themes in Translation Studies, 15, 106-120.

\title{
"And then the Germans came to town": The lived experiences of an interpreter in Finland during the Second World War
}

\section{Pekka Kujamäki}

University of Graz, Austria

pekka.kujamaeki@uni-graz.at

During World War II, both the Finnish Army and its ally Germany were dependent on mediation practices provided by military personnel or civilians in the linguistic, cultural and ideological intersections of the given conflicts. By drawing on two autobiographical manuscripts - one written immediately after the war and the other later in the 1990s - this article examines the experiences of a female civilian interpreter engaged by the German Army from 1942 to 1945. In addition to directing attention to ordinary people in wartime translational tasks, this article contrasts the value of such post-hoc accounts in the historical translation analysis against the constraints imposed on them through their embeddedness in a certain communicative situation. It shows, furthermore, how the change in this communicative situation imposes changes on the writer's emotional involvement and how this change mirrors her own stance towards the given narrative framework.

\section{Introduction}

The following discussion on the experiences of an interpreter in times of war is placed in the Finnish-German military alliance (1941-1944), which created a dynamic, multilingual space of Finnish-German administrative, military, ideological and cultural negotiations lasting four years. In this space, a variety of translation and interpreting practices were called for, not only to sustain the interaction and interconnections in joint military projects but also to support the coexistence of Finnish civilians and German military forces. By June 1942, Hitler's Operation Barbarossa had brought approximately 200,000 German soldiers to the Far North; their presence was visible practically everywhere and to everyone, and it coloured the whole range of human contacts with translation and interpreting as a daily routine. Depending on the specific context, these mediation practices were managed by military personnel (notably German or Finnish military interpreters and Finnish liaison officers) or civilians (women and children) and prisoners-of-war with sufficient language skills (Kujamäki, 2012).

To demonstrate one part of the wartime translation and interpreting practices and the potential agency of civilian interpreters, this article 
analyses two autobiographic manuscripts by Lahja Ikonen, who was recruited in 1942 as an interpreter for a German supply depot (“Armeeverpflegungslager 517") in Hyrynsalmi, eastern Finland. During her service, Ikonen took notes on her daily tasks, colleagues and local people and recorded her feelings about living in a male military space far away from home. These primary diary notes served later as the basis for her actual autobiographical texts, which serve here as a view into both her life and day-to-day translation and interpreting routines among the German troops.

This study has two objectives: first, at a general level, it discusses the methodological question of what kind of information can be obtained from personal accounts for the reconstruction of military translation cultures and how a chronological distance between the reported experiences and the moment of writing could constrain them. Second, and more importantly, it aims to make visible the ordinary people embodying the intercultural spaces of conflict who, more often than not, are sidelined in military historiography. All this defines the present approach as microhistorical: its primary focus is on an everyday translation and interpreting practice as experienced by a subaltern individual with complex relationships in the military and civilian social structures (Iggers, 2005; Munday, 2014).

\section{Materials}

Lahja Ikonen's story is drawn from two autobiographical manuscripts written in Finnish. ${ }^{1}$ First, as the primary source, the account comes from selected pages of a 177-page manuscript titled The Diary (Ikonen, 1991) for the purposes of this paper. The text contains several deictic references (e.g. "if I hadn't quite recently [13.4.1991]") that explain the text production time several decades after the war. The manuscript parts at hand (Ikonen, 1991, pp. 17-48) cover the years 1933-1945, but the main area of interest is located in the diary pages that focus on Ikonen's time and work in the German supply depot in Hyrynsalmi from 1942 to 1944 and with the withdrawing troops in northern Finland and Norway from 1944 and 1945.

As a second source, the article draws on Matkamuistelma 3/9/443/9/1945 ("Travel Memoirs", Ikonen, n.d.), a 62-page narrative of Ikonen's journey with the German Army through Finnish Lapland to Norway on her way to Germany in the 12 months following Finland's disengagement from the war and the termination of the Finnish-German military alliance. Again, individual textual clues (e.g., "I can tell that my mother has aged a lot in the past year") place the text production in 1946 or 1947. The clues indicate further that the "Travel Memoirs" are closely based on Ikonen's handwritten war-time diary notes, an assumption that is also communicated by her daughters; the original war-time diaries, however, have been lost. As such, as illustrated in the overview in Figure 1, the two texts overlap 
partially in time, thus offering themselves for parallel reading and comparisons, for example with respect to the effects of time difference between the reported experiences and the moment of writing.

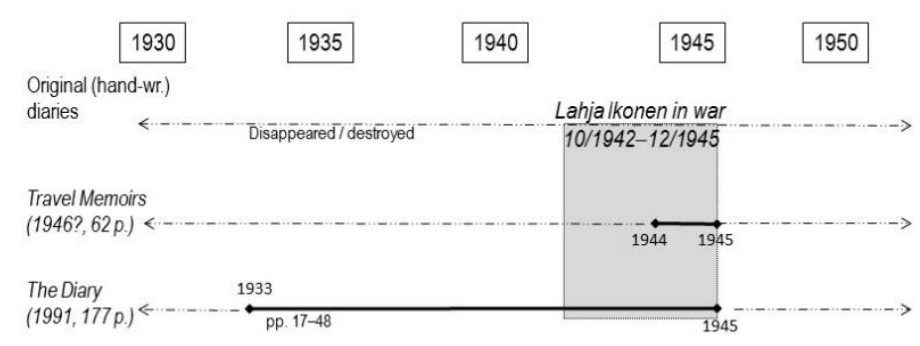

Figure 1: Lahja Ikonen's texts on a timeline

Altogether the autobiographic sources of this study can be characterized as "overtly mediated testimonies" (Munday, 2014, p. 68) that result not only from the time difference but also from a series of rewriting and selection processes which occurred before ending up on the researcher's desk. As shown by Munday (2014), there seems to be no consensus among historians on the value and limitations of such basically subjective representations of events and experiences. Their value lies essentially in their power to highlight the human agency and engagement in the given historical moment, but are, however, constrained by the "mediation of memory" that is "inherently unreliable" (Munday, 2014, p. 68).

This general view, though intuitively easy to agree with, deserves some further attention. Indeed, personal memoirs such as these are probably the only available window into the lives and experiences of interpreters, who are mostly invisible in the military archives and other official papers. As a consequence, such accounts are indispensable as they are the very few sources that the reconstruction of the (mostly unofficial) details of military translation cultures can be based on. Regarding the limitations of reliability of our specific materials, however, it is uncertain to what extent it should be measured against the weaknesses of memory only. In the following it is argued that the source criticism should consider the writing and rewriting processes as embedded in a communicative situation, as determined by a set of social frameworks or narratives, and as guided by communicative purposes that the texts are imagined or intended to fulfil. 


\section{Framing personal experiences}

In his book on schemes of everyday experience, Erving Goffman (1974) argues that human experiences and day-to-day acts of life "are understandable because of some primary framework (or frameworks) that inform them" (p. 26). The primary frameworks may be natural ("the interpreter's car accident was caused by extreme snow conditions") or social ("the interpreter's language skills made her an interpreter"), the latter providing the focus of Goffman's analysis. He speaks of "socially guided doings" (Goffman, 1974, p. 22), of acts or events perceived and organized against a set of frames or schemes that constitute a "belief system" (Goffman, 1974, p. 27). Seen at this very general level, the concept of "framing" is not too distant from the notion of "narratives" provided by narrative theory (e.g., Somers, 1992; Somers \& Gibson, 1994) as discussed in detail by Mona Baker (2006) from the perspective of translators' and interpreters' agency; similar to frames, narratives make sense of the world and of our relationship to it and to other people by virtue of "systemiz[ing] experience by ordering events to each other - temporally, spatially, socially" (Baker, 2006, p. 10). Narratives comprise "public and personal 'stories' that we subscribe to and that guide our behavior" (Baker, 2006, p. 19) and can be ontological (a person's own story of her identity and place in the world), collective (e.g., "Finland's national struggle for independency"), conceptual (e.g., "military contexts establish their own translation cultures") or meta-narratives (e.g., Hitler's urge for Lebensraum) (Baker, 2006, pp. 28-44).

Whether conceptualized as frameworks or narratives, the main point to build our argument on is that we are never free from such structures and, more importantly, that these structures change in time and space. Drawing on Somers and Gibson (1994), Baker points to the temporality of our perceptions, that "our narratives of the world, are 'history laden' $[. .$.$] and$ that history, in turn, is a function of narrativity" (Baker, 2006, p. 55; on "frame change through time" see Goffman, 1974, p. 54). Therefore, to return to the present material, both the limitations and the value of Lahja Ikonen's autobiographic texts could be established with the narrative structures that frame her experiences and the written accounts. In other words, people change with time and the narratives that are constitutive for the zeitgeist, and these changes become observable, in one way or another, in the stories they write down.

In addition to this, there is the question of how or through which medium the accounts are communicated, and for whom. In our case, we have information on lost original handwritten diaries and access to two different versions of autobiographical memoirs that are originally based on the former. Goffman refers to such documentation - whether written or other "replicative records" (Goffman, 1974, p. 68) - as "technical redoings" (Goffman, 1974, p. 58) that in turn constitute one sub-category of "keys". In Goffman's toolbox, the concept of "keyings" (Goffman, 
1974, pp. 40-70) represents an umbrella term for processes in which a given actual activity undergoes a transformation, the degree of which ultimately depends on the key in question. Goffman himself draws first and foremost on dramatic keyings (e.g., a script of activity is transformed into a "novel" and, in turn, transformed into a "movie"), but "diary" or "memoir" provide us with similar examples of "keys" that frame the act of communication with the imagined, implicit or explicitly defined audience and give rise to reductions, abstractions or other transformations of the original events. While the first writing stage can be discussed in terms of a writer having a dialogue with her notebook in the middle of war, in the following stages new readers can be imagined as the writer's audience: For example, in the post-war "Travel Memoirs" Lahja Ikonen directly addresses her readers by asking them to visualize the Norwegian landscapes (Ikonen, n.d., p. 37) or to understand the motivations for her actions from a certain perspective (Ikonen, n.d., p. 48). In contrast to this, The Diary was written later as "a memento for generations to come" 2 and it at least implicitly engages Ikonen's daughters in the interaction.

When read parallel, these shifts in time and readership emerge most visibly in Ikonen's reflections on emotional experiences and, respectively, self-distancing from the emotions as well as from reported events and narratives framing her experiences. In other words, there is a notable difference in the affective aspect or "emotional dispositions" (Keen, 2011, p. 29) that the two texts reveal as a response to the events and experiences and the public narratives that frame them. Thus, bringing all constraints together, the present sources could be characterized as functions of time, audience, narratives and "affect memory", the latter signifying the "emotionally expressed feeling that recurs when recalling a significant experience" (Koskinen, 2012, p. 24). Time not only effects changes in the narrative structures surrounding us but also drains the affect memory, and all this has an effect on our views of past experiences, thus "making us perhaps subconsciously look for reasons or excuses to distance ourselves" from them (Koskinen, 2012, p. 26). Whether in literary fiction (Andringa, 1996) or in personal memoirs, one obvious motivation for such emotional distancing could be the intention to regulate respective readers' emotional involvement and response.

Seen from this angle, the value of autobiographic, mediated accounts lies, similarly to personal letters (Andringa, 2011), not only in their potential information about the historical context but also in the writer's affective voice. As will be illustrated below, this voice may imply how Ikonen positioned herself in a military conflict that was defined by sides, allegiances and oppositions, and how this positioning changes along with new keyings.

Much of what is said above contributes to the (almost platitudinous) illustration of the translation historian as an outsider to the communication that the personal memoirs perform. As regards the value and credibility of the materials in the present study, however, this position provides some 
clear advantages. Since the given memoirs are not written for the present historian as a response to his specific questions, there is no immediate reason to question the authenticity of the information on war-time interpreting - on account of being self-serving (see Munday, 2014, p. 69) or paying lip service to the historian.

\section{A story of an unknown interpreter in war}

Lahja (Inkeri Irja) Ikonen was born in April 1922 in Vyborg (Finnish Viipuri). The family lived on the Karelian Peninsula until the end of the Winter War (1939-1940), when they remained on the Russian side of the newly defined border. The family moved to Imatra and from there to Savonlinna. In 1941, Ikonen went further north to Kajaani to work in her relatives' shoe shop, where she was recruited for war-time interpreting tasks. After the war, she returned to Imatra, where she began a career in the local metal industry. In the post-war years, Ikonen maintained contacts with her German friends and a close friendship with her Swiss penpal. She also freelanced as an interpreter in Finland and abroad. Ikonen had a lasting fascination for languages and, as her final endeavor, she started to learn Russian. She died in August 2014 at the age of 92. ${ }^{3}$

In the following, Lahja Ikonen's personal memoirs are read as closely as possible with a focus on her interpreting activity and life with the German troops in 1942-1945. At first, the voice is given to the interpreter herself. Her story is then followed by a discussion on how it contributes to the reconstruction of military translation cultures in World War II in Finland and how the two memoirs seem to signal the interpreter's allegiances quite differently.

\section{1. "There was this young girl who knew German"}

In 1941, during the period between the Winter War and the Continuation War, Finns were recovering from the first war in anticipation of the latter. Lahja Ikonen came to Kajaani to assist her relatives in their shoe shop. She learnt her trade by studying different leather qualities, selling waxed thread to local "cobblers' brats" and accompanying her uncle "Pappa" to market places to sell rubber boots and other working shoes (Ikonen, 1991, p. 32).

The Continuation War broke out in summer 1941, a campaign against the Soviet Union through which Finland became attached to Hitler's Operation Barbarossa. The German brothers-in-arms were present all over northern Finland, soon also in Kajaani:

And then German soldiers came to town from somewhere North for shopping, to buy slippers or gloves and things like that. I remember once, when a soldier came and asked for "Hausschuhen" [...]. I had 
never heard of that name and it reminded me phonetically of "Handschuhen" ( gloves), so I presented him with a box of gloves. Finally he managed to use the word "Pantoffel" and so we closed the deal. Since then the rumor went around among Germans that there was this young girl in the shoe shop who "knew" German. (Ikonen, 1991, p. 33)

The German Army had a major supply depot, Armeeverpflegungslager 517, in Hyrynsalmi, some 60 kilometres northeast of Kajaani. When in town, the soldiers developed the habit of looking for Ikonen's shop first not to buy shoes but to have their shopping lists translated before moving on to other shops. Pappa saw an opportunity to bargain with the Germans, and soon, with Ikonen's help, winter shoes were exchanged for German tobacco, coffee and brandy, all hard currencies for Pappa to use in his business with the local store holders in times of war-time shortage.

Ikonen's German developed little by little and she was engaged as an "interpreter" by more and more shops: "Over the telephone it was sometimes difficult to use the foreign language. It was easier face to face, because you could use your hands as further help" (Ikonen, 1991, p. 34). News of the German-speaking girl finally reached the local German headquarters, and soon Ikonen received a telephone call from the Finnish headquarters in Hyrynsalmi offering her a position as an interpreter and a bureau assistant in the local German supply depot in Hyrynsalmi.

Ikonen accepted the invitation to an interview, which started with a relaxed conversation: "I understood alright, because they spoke slowly" (Ikonen, 1991, p. 35). Then she was asked to type a few dictations, which was not very difficult either "because by then I had been in correspondence a long time with Lisbeth [her Swiss penpal] and otherwise preoccupied with German" (Ikonen, 1991, p. 35). As the final test, however, she was asked to explain German construction plans to a Finnish contractor, Tolppanen, who would soon come to town to discuss them. Ikonen became nervous:

[...] I had absolutely no clue about the special vocabulary. When Tolppanen came - I knew him through Pappa from Kajaani - I said that it depended on him whether I got this job or not. He asked me if I knew what a "drawing" was in German. I knew that alright. He said that when he gets hold of the drawings, I could tell him fairy tales, he would figure it out anyway. And so it went, and the job was mine. (Ikonen, 1991, p. 35)

A couple of weeks later, in October 1942, Ikonen started as a secretary and an interpreter ("Als Schreibkraft und Dolmetscherin") earning 2750 Marks per month plus full benefits, "2000 Marks more per month than in Kajaani" (Ikonen, 1991, p. 35). Her uncle did not really support the decision, "but what could he do, stubborn as I was" (Ikonen, 1991, p. 35). 


\subsection{Working for the German military}

As Lahja Ikonen recollects, her interpreting tasks consisted mainly of discussions between Finnish construction workers and German commissioners, "otherwise, as the only Finn in camp, I just had to try to speak German day in, day out" (Ikonen, 1991, p. 36). The depot supplied several military units, and as her language skills improved, Ikonen was commissioned with the bookkeeping of supplies going out or coming in as well as the records of the waste of meat, sausages and chocolate, either to be recorded as frozen or melted products or - in case of wine - as broken bottles:

Somehow I had the feeling when writing those records that the readers would be very well aware of where the lost kilograms and litres had disappeared, for "better purposes" so to speak, but you had to produce text according to German thoroughness all the same. (Ikonen, 1991, p. 36)

Ikonen lived in the barracks together with soldiers of the German Mountain Army. Her immediate superiors and colleagues were German camp and bureau officers, but in her daily routine she was continuously surrounded by soldiers of all ranks and from different areas of the Reich. In addition to them, there were Red Army prisoners-of-war, in particular Germanspeaking Ukrainian deserters, "young boys working in the kitchens and heating up the rooms" (Ikonen, 1991, p. 38). One of them, a "metal-teeth Vassili", was responsible for Ikonen's accommodations.

Only three other women are mentioned as Ikonen's colleagues. Two of them came from southern Finland to stay only briefly in the unit; the third one was hired from the local village and stayed until the end of war. Their free time, "not that there was too much leisure", was used for regular visits to local saunas, for picnics and sunbathing as well as for "occasional parties" (Ikonen, 1991, p. 40). April 20 was an annual holiday, Hitler's birthday, and all staff collected around the radio to listen to his speech:

I can't remember whether I understood half of those speeches, him shouting and the others cheering in between. Such was the time then. I believe there were propaganda men among us, too, who made certain that Hitler's support wouldn't sink and dissidents couldn't make their voice heard. I was like a blind kitten whose eyes were not open, as yet. (Ikonen, 1991, p. 40)

\subsection{A mission}

The war continued. On the Karelian Peninsula, the Finnish Army was making preparations for a large Red Army offensive that would start later 
in June 1944. As part of these preparations, a Finnish army group was to be transferred from Uhtua in Eastern Karelia southwards on the Karelian Peninsula, whereas the German Mountain Army would take over the Finnish positions. ${ }^{4}$ For the negotiations on these troop transfers, the interpreter was summoned:

I can't recall the exact date, but it was snow time, when our camp commander received a request from the AOK (Armeeoberkommando) to borrow the depot unit's interpreter for a couple of days. It wasn't said what it was all about, nor where I would go. In a briefing in my own department I was told not to talk about where I was going, what I would hear or see during the detachment. Such confidentiality briefings were otherwise regular und we interpreters were requested not to have conversations in Finnish, even when among ourselves. Well, I had an adventurous spirit and had learned not to ask too many questions. (Ikonen, 1991, p. 40)

Lahja Ikonen was taken close to the Finnish-Russian border and then further on towards Uhtua, where she then interpreted in consultations in which the Finnish and German army groups negotiated a written agreement on supply issues, "and when the discussions ended, I stayed up very late and copied out the papers" (Ikonen, 1991, p. 41). The short nights were spent in a dugout plagued by large numbers of bedbugs; "it still makes me shiver when I think of it" (Ikonen, 1991, p. 41). Ikonen remembers:

I must have been half asleep, but I felt I was doing an important job and you had to stay sharp to get everything right. It was no problem for me to translate these issues, as I was dealing with supplies and such vocabulary all the time. Practice is the best way to learn languages. (Ikonen, 1991, p. 41)

Much later, in her retirement, Ikonen benefited from this mission. The short service for the Finnish Army provided her with a personal front identification number, which later guaranteed her a war veteran's pension. Ikonen comments: "So, I have been at war and returned. First I thought I was on the 'wrong side' and I wouldn't have the right to get the identification number, but I did” (Ikonen, 1991, p. 41).

\subsection{The tables turn}

A few months later, the Karelian Offensive of the Red Army led to separate peace negotiations between the USSR and Finland and consequently to both Finland's disengagement from the war and to the termination of the Finnish-German brotherhood-in-arms. On 3 September 1944, Ikonen and 
her colleague were visiting their friends in Hyrynsalmi when they heard the radio announcement that Finland had agreed on peace terms with the USSR and that "the Finns should chase the Germans out of the country" (Ikonen, 1991, p. 41).

Ikonen had already made plans in anticipation of something like this: "The rumours had it that the Russian troops would occupy northern Finland and hang all Finns who had co-operated with the Germans" (Ikonen, 1991, p. 41). Her plan was to go to Nuremberg to a German soldier's family. She had been in correspondence with them over the war years, deposited part of her salary for them and agreed to take a job in their factory after the war: "So I had already decided to go to Germany, anyway, and as the news came that the alliance had turned into hostilities and the Russians occupied northern Finland, the decision was made" (Ikonen, 1991, p. 42).

Her superiors did not oppose her plan to join the retiring troops; she had become a trusted person, one of them, and had been deemed useful in the new situation, too. Ikonen's mother tried to persuade her to give up the plan, without success:

I even advised her and my father to flee to Sweden. It was the panicked mood at that time. Afterwards I have regretted the worry and shame that I caused my parents by going with the foreign army towards an unknown destiny. (Ikonen, 1991, p. 42)

Lahja left Hyrynsalmi for Norway and further to Germany with the German troops on 14 September 1944. However, she would not ever reach her final destination, Nuremberg. ${ }^{5}$ Already on the first evening, she was sent to a German office in Rovaniemi for interpreting and secretarial tasks. There she soon realized that the alliance was indeed terminated: for the first time, the former ally bombed the German offices and troops, and a personal curfew was imposed on Ikonen to protect her from being captured by the Finns. Coincidentally, however, she came into contact with a Finnish liaison officer, who couriered a letter to Ikonen's parents as a sign she was alive: "As I learned later, there was a rumour going round in Kajaani that I had been shot in Taivalkoski” (Ikonen, 1991, p. 42).

In Rovaniemi, Ikonen assisted in offices and telephone exchanges, burned papers, packed important papers and office supplies in boxes. For her, the evacuation proceeded in October through Ivalo and over the border to Norway, where she finally worked for several months in a German army clothing depot (Armeebekleidungsamt, $A B A$ ) in Saetermoen, first as a bookkeeper and later as the leader and mediator of foreign female workers in the camp. In spring 1945, after Hitler's suicide and the unconditional surrender of the German Army, Ikonen was interned by American troops along with other Finnish women in Norway and later transferred to Finland, where they were to be interrogated by the Finnish Secret Police. At the 
border to Tornio, Finland, the local people were waiting for the transport, some of them with cobblestones in their hands.

\subsection{Context-specific generalizations}

When put together with other accounts of war-time experiences, it is possible to filter out convergences that point to certain patterns of the translation culture in the historical-political context explored here. First, Ikonen's description of how she was hired by the German military repeats a story told by many in the post-war accounts and as such once more reflects the permanent shortage of interpreters in the Finnish-German space of northern Finland (see Junila, 2000, p. 323). The joint FinnishGerman campaign as well as the co-existence of Finnish civilians and the German Mountain Army constituted a wealth of opportunities and forms of communication ranging from occasional contacts to daily routines in work and social life and up to negotiations at different official levels. Moderate, even poor, linguistic skills were suddenly an asset of great economic and social value. The minimal linguistic criterion was easily met by many Finnish girls and boys as, up to the 1940s, German was the first foreign language learned in Finnish schools. Knowledge of German opened up ways of doing business with foreign soldiers and, for many girls, women and adolescent boys, short- or longer-term meditation tasks in the German army.

What is emerging, then, is a profile of an accidental interpreter required for the intercultures the war created; accidentally disclosed as having the relevant linguistic skills, the person is perhaps first called upon or she volunteers as a "habitualized interpreter" in the given multilingual space. After such unofficial mediation practice, she later becomes officially recruited in institutions, performing "institutionalized" translation and interpreting tasks. (On the concepts and practices of "habitualized" and "institutionalized" translation see Wolf, 2012, pp. 87-119 and 2015, pp. 49-66). The integration into a military unit may express itself in different forms, through salary and other economic or social benefits and sometimes through uniform and military insignia. But in addition to those, the integration is often signified through the interpreter's physical proximity to the unit in question, which may or may not turn into an affective proximity that - as is discussed further below - finds its expression in the post-hoc accounts of the given interpreters.

The profile of an accidental interpreter is closely connected with the second common feature that emerges from many accounts: in the translation culture of the time - and this observation surfaces at all levels and in all areas of official, institutionalized translation and interpreting language skills equalled interpreting skills. There was no training before or during the engagement; the only real prerequisite for the job was the superficially evaluated command of the two languages in question. 
Everything else involved in the mediation tasks was learned by doing or, in Ikonen's summary: "Practice is the best way to learn languages." Together, the two common features refer back, as one possible explanation, to the question of why the issue of translation and interpreting is so little discussed in the autobiographical accounts of past interpreters: the engagement was too short and also covered too many tasks beyond translation and interpreting for a translational identity to emerge and to be discussed later.

Thirdly, Ikonen's autobiographical narrative further illustrates how lucrative working for the Germans in general was. Her account clarifies in detail that, in comparison to the normal wages of unqualified young women of that time in Finland, the interpreters received substantial compensation that was equivalent to that of an educated school teacher. Together with other material benefits - first and foremost food supplies that helped many families to ease the daily constraints of war-time rationing - the salary must have made interpreting tasks very attractive for those given such opportunities.

\subsection{The two-tempered interpreter?}

Lahja Ikonen's story shows very clearly that she truly wanted to take advantage of the opportunity and become an interpreter for the German unit: she travelled to the job interview against her uncle's explicit warnings and even engaged the Finnish contractor in a short, benevolent conspiracy against her future employer to turn the potentially unfavourable test situation to her advantage. Thereafter, Ikonen developed a close allegiance to the troops she worked for - a loyalty most visible in her determination to leave Finland with the German troops and start a new life in Germany. But the allegiance also becomes evident from her self-reflective, slightly surprised commentary on the Finnish war veteran's pension granted on account of her short-term assignment for the Finnish Army. Written in retrospect, her remark "first I thought I was on the "wrong side" obviously reflects not only her hostile experiences on the Finnish border but also the interrogations conducted by the Finnish Secret Police (at that time already under the close supervision of the Allied Control Commission) in the internment camp of Hanko.

Interestingly, the two autobiographical texts illustrate this allegiance in somewhat different emotional hues, thus occasionally creating the impression that we are actually dealing with two different authors:

The departure from Hyrynsalmi turned out to be much more bitter than expected, as my mother suddenly arrived and wanted to take me home. I was hard and cold, little affected by her tears, just explained in a cold calculating manner why I was leaving and advised her to flee with my father to Sweden. She left the following 
morning with a heavy heart and tears in her eyes [...] (Ikonen, n.d., p. 2).

Most sad was when my mother suddenly came to Hyrynsalmi and when we departed in tears, as I didn't see any other solution in that situation. I even advised her and father to flee to Sweden. Such was the panic mentality then (Ikonen, 1991, p. 42).

The young, self-assured, occasionally even defiant narrator of the former text becomes the calmer, analytical and relaxed narrator in the latter who is observing and describing the past with less emotional engagement. "Travel Memoirs" features an interpreter with a passionate loyalty to the German side, who was instantly ready to follow "our unit out of the way of bolshevism" and join "my brothers-in-war", first full of "enthusiasm for serving my new fatherland" but then upset by Hitler's death and the unconditional capitulation - a young woman who would never have thought "that Germany could lose the war" (Ikonen, s.a., p. 1, pp. 48-49). In the latter retrospective the war-time narratives remain in the background and the personal commitments are reported from a greater distance. The commentary "I was like a blind kitten whose eyes were not open, as yet" (Ikonen, 1991, p. 40) reads like an excuse, not denying but clearly modifying her emotional involvement as well as her personal position in the reported events.

\section{Conclusion}

In this article, Lahja Ikonen's autobiographic manuscripts were discussed as post-hoc accounts constrained by time, audience and social frameworks. Regarding the latter, it is worth noting that this particular article is one further framing of Ikonen's experiences created by a translation historian who has approached the sources from his own expectations, evaluated the relevance of individual details in them, and then "translated" all this into a new story ("keying") that serves his scholarly intentions to sketch details of military translation cultures in Finland.

Ikonen's texts make up a rich source of information on her recruitment, day-to-day tasks, colleagues, benefits and general working conditions. Beyond the description of her initial feelings of linguistic and terminological insufficiency, however, the material contains few reflections on the interpreting work or translation problems she had to contend with and no conceptualization of translation and interpreting. But such reflections are perhaps not to be expected: we are not dealing with the memoirs of an interpreter, but of a human being whose identity and intention to write down her recollections cannot be reduced to her activity as a war-time interpreter. 
In her discussion on the memoirs of prominent interpreters such as Eugen Dollman, Paul Otto Schmidt or Valentin Bereschkow, who all performed in the core of international politics, Dörte Andres (2001) points out that writing memoirs gave many of them the opportunity to express their own personality or "ego" instead of the person engaged in the activity of interpreting, the "alter ego" who is always expressing someone else's thoughts and feelings. This is why so many of them, Andres argues, focus their attention on something other than their work as an "alter ego" and why translation and interpreting feature in their texts less often than expected (Andres, 2001, pp. 34-36; see also Andres, 2012). In Goffman's (1974, pp. 269-270) terminology, it is important to distinguish between the individual person and the "particular role, capacity, or function" that she realizes in the given situation. This is an important reminder for the analyses of mediating people in times of war, because, in most cases, their roles or capacities as interpreters or translators may have been very temporary. Therefore, if a translation historian wishes to understand the interpreter, her work, motivations and positions, he or she needs to reach out beyond his or her narrow expectations and to look at the human being as a whole, not only at the (often temporary) role she has been given. If the reconstruction remains inaccurate, it is not necessarily the distance from the events that causes the inaccuracy, but rather the fact that the memoirs are not solely about translation. Other stories, when accumulated, can fill in the gaps.

\section{References}

Andres, D. (2001). Dolmetscher-Memoiristen: Zwischen alter ego und ego. In T. Lindner (Ed.), Moderne Sprachen (pp. 23-37). Wien: Edition Praesens.

Andres, D. (2012). Erwin Weit: Gratwanderung eines Dolmetschers. In A. F. Kelletat \& A. Meger (Eds.), Worte und Wendungen: Texte für Erika Worbs mit Dank für zwei Jahrzehnte Germersheim (pp. 11-19). Berlin: Saxa.

Andringa, E. (1996). Effects of 'narrative distance' on readers' emotional involvement and response. Poetics, 23, 431-452.

Andringa, E. (2011). Poetics of emotion in times of agony: Letters from exile, 19331940. Poetics Today, 32(1), 129-169.

Baker, M. (2006). Translation and conflict: A narrative account. London: Routledge.

Goffman, E. (1974/1986). Frame analysis: An essay on the organization of experience. With a new foreword by Bennett Berger. Boston, MA: Northeastern University Press.

Iggers, G. G. (2005). Historiography in the twentieth century: From scientific objectivity to the postmodern challenge (2nd ed.). Middletown, CT: Wesleyan.

Ikonen, L. (1991). The Diary. Unpublished autobiographic manuscript.

Ikonen, L. (n.d.). Matkamuistelma 3/9/44-3/9/1945. Unpublished autobiographic manuscript. 
Junila, M. (2000). Kotirintaman aseveljeyttä: Suomalaisen siviiliväestön ja saksalaisen sotaväen rinnakkaiselo Pohjois-Suomessa 1941-1944. Helsinki: SKS.

Keen, S. (2011). Introduction: Narrative and the emotions. Poetics Today, 32(1), 1-53. Koskinen, K. (2012). Domestication, foreignization and the modulation of affect. In H. Kemppanen, M. Jänis, \& A. Belikova (Eds.), Domestication and foreignization in translation studies (pp. 13-32). Berlin: Frank \& Timme.

Kujamäki, P. (2012). Mediating for the Third Reich: On military translation cultures in World War II in Northern Finland. In H. Footitt \& M. Kelly (Eds.), Languages and the military: Alliances, occupation and peace building (pp. 86-99). Basingstoke: Palgrave Macmillan.

Leskinen, J., \& Juutilainen, A. (2005). Jatkosodan pikkujättiläinen. Helsinki: WSOY.

Munday, J. (2014). Using primary sources to produce a microhistory of translation and translators: Theoretical and methodological concerns. The Translator, 20(1), $64-80$.

Somers, M. (1992). Narrativity, narrative identity, and social action: Rethinking English working-class formation. Social Science History, 16(4), 591-630.

Somers, M., \& Gibson, G. (1994). Reclaiming the epistemological "other": Narrative and the social constitution of identity. In C. Calhoun (Ed.), Social theory and the politics of identity (pp. 37-99). Oxford: Blackwell.

Wolf, M. (2012). Die vielsprachige Seele Kakaniens: Übersetzung und Dolmetschen in der Habsburgermonarchie 1848 bis 1918. Vienna: Böhlau.

Wolf, M. (2015). The Habsburg monarchy's many-languaged soul: Translating and interpreting, 1848-1918. (Translated by Kate Sturge.) Amsterdam: John Benjamins.

1 I am grateful to Lahja Ikonen's daughters for giving us access to her personal papers and for providing us with further information on her life as well as on the given texts. All quotations from these materials are my translations.

2 Personal communication with Lahja Ikonen's daughters.

3 Personal communication with Lahja Ikonen's daughters.

4 See Leskinen and Juutilainen (2007, pp. 338-339). I thank Niina Syrjänen for bringing this source to my attention.

5 From here on we add details to the story from Ikonen's earlier account about the journey through Lapland in September 1944 to September 1945. 